\title{
Trends in fetal indications for termination of pregnancy between 2002 and 2010 at a tertiary referral centre
}

\author{
Üçücü basamak referans merkezinde 2002-2010 yılları arasında gebelik \\ terminasyonuna yol açan fetal endikasyonların değişimi
}

\author{
Aytül Çorbacıŏ̆lu' ${ }^{1}$, Halil Aslan², Serdar Aydın², Özgür Akbayır², Fırat Ersan², Verda Alpay², Hediye Dağdeviren², Songül Kısacık² \\ ${ }^{\prime}$ Department of Gynecology and Obstetrics, İstanbul University, İstanbul Faculty of Medicine, İstanbul, Turkey \\ ${ }^{2}$ Department of Gynecology and Obstetrics, Istanbul Kanuni Sultan Süleyman Research and Teaching Hospital, istanbul, Turkey
}

\section{Abstract}

Objective: We reviewed the data of the termination of pregnancy (TOP) cases between 2002 and 2010 to evaluate the changes in fetal indications for both early and late TOPs in this period.

Material and Methods: The data of 962 TOP cases were analysed in two groups according to the periods as in 2002-2006 and 2007-2010. The women were also subdivided into two categories according to their gestational age; <23 weeks' gestation (early termination) and $\geq 23$ weeks' gestation (late termination).

Results: Four hundred and fifty-eight (47.6\%) of TOPs were performed between 2002 and 2006 (Group 1) and 504 (52.3\%) were performed between 2007 and 2010 (Group 2). The number of early ( $<23$ weeks) and late ( $\geq 23$ weeks) terminations were $583(60.6 \%)$ and 379 (39.3\%), respectively. The vast majority of anomalies were central nervous sytem malformations (51.8\%). They were followed by multiple anomalies (10.2\%) and chromosomal anomalies (9.4\%). Chromosomal and cardiovascular system anomalies were significantly higher in $2007-2010$ in comparison to $2002-2006(\mathrm{p}<0.0001$ and $\mathrm{p}=0.002$, respectively). There was no statistically significant difference between the fetal indications that led to early termination compared to those that led to late termination.

Conclusion: The distribution of indications for TOP was influenced by the development in prenatal screening policy, resulting in a significant increase in terminations due to chromosomal and cardiovascular system anomalies. Cultural, educational, religious and legal factors cause differences in the indications for TOP as well as the gestational age that TOPS are performed.

(J Turkish-German Gynecol Assoc 2012; 13: 85-90)

Key words: Termination of pregnancy, fetal anomaly, chromosomal anomaly, ultrasound, prenatal screening

Received: 07 February, 2012

Accepted: 01 March 2012
Özet

Amaç: 2002-2010 yılları arasında gerçekleşmiş olan gebelik terminasyonlarına ait verilerin geriye dönük incelenmesi ile bu dönemdeki erken ve geç terminasyonların fetal endikasyonlarında görülen değişimi değerlendirmek.

Gereç ve Yöntemler: Dokuzyüz altmış iki terminasyon olgusuna ait veriler 2002-2006 ve 2007-2010 olmak üzere iki ayrı dönemde incelendi. Olgular ayrıca gebelik haftalarına göre iki alt gruba ayrıldı; $<23$ hafta (erken terminasyon) ve $\geq 23$ hafta (geç terminasyon).

Bulgular: Terminasyonların 458'i (\%47.6) 2002 ve 2006 yılları arasında (Grup 1) ve 504'ü (\%52.3) 2007 ve 2010 ylları arasında (Grup 2) yapıldı. Erken ( $<23$ hafta) ve geç ( $\geq 23$ hafta) terminasyonların sayısı sırasıyla 585 (\%60.6) ve 379 (\%39.3) idi. Anomalilerin büyük çoğunluğunu santral sinir sistemi malformasyonları oluşturuyordu (\%51.8). Bunu çoklu anomaliler (\%10.2) ve kromozom anomalileri (\%9.4) izliyordu. Kromozom ve kardiyovaskuler sistem anomalileri 2007-2010 yllarında 2002-2006 yıllarına kıyasla anlamlı şekilde artış gösterdi (sırasıyla $p<0.0001$ and $p=0.002$ ). Erken terminasyon ve geç terminasyona neden olan fetal endikasyonlar arasında istatistiksel olarak anlamlı bir fark saptanmadi.

Sonuç: Terminasyon endikasyonlarının dağılımı prenatal tarama politikalarındaki gelişimden etkilenmiş, buna bağlı olarak kromozom ve kardiyovaskuler sistem anomalileri nedeniyle yapılan terminasyonların sayısı önemli ölçüde artmıştır. Kültürel, eğitimsel, dini ve yasal faktörler terminasyon yapıldığı gebelik haftasının yanı sıra terminasyon endikasyonlarında da değişikliklere yol açmaktadır.

(J Turkish-German Gynecol Assoc 2012; 13: 85-90)

Anahtar kelimeler: Gebelik terminasyonu, fetal anomali, koromozom anomalisi, ultrason, prenatal tarama

Geliş Tarihi: 07 Şubat 2012

Kabul Tarihi: 01 Mart 2012

\section{Introduction}

As a consequence of advances in medical technology and the development of universal prenatal screening policies, increasingly more anomalies are being detected at an early stage of pregnancy, and this results in an increased rate of the termination of pregnancy (TOP). In the case of severe or lethal anomalies, some future parents prefer to interrupt the pregnancy. Several factors such as gestational age, involvement of the central nervous system, severity of anomaly, and presence of chromosomal abnormalities affect the decision of TOP (1).

The laws on performing TOP vary between countries, and may specify: 1) no upper gestational age limit for any TOP, 2) 
no upper gestational age limit for lethal anomalies, 3) an upper gestational age limit for any TOP, 4) no TOP at any gestational age (2). Since 1983, Turkish law has permitted the TOP at any period of gestation if the ongoing pregnancy is hazardous for a woman's health and/or fetus has a high risk of severe disability or incurable fatal disease (3). Approval for the TOP can be given by two specialists when there is a maternal or fetal reason justifying the TOP.

In the present paper, we aimed to review the TOP cases between 2002 and 2010 in our clinic, in order to seek the alterations in fetal indications of both early and late terminations within the last nine years.

\section{Material and Method}

We analysed the data of TOP cases in the Department of Maternal Fetal Medicine between January 2002 and December 2010. Our hospital serves as a tertiary referral center and there were 162,000 deliveries during the study period. A total of 962 women underwent TOP because of fetal anomalies. Ultrasonographic examinations were carried out by four specialists using a Voluson 730 Expert (GE Healthcare). First trimester Down syndrome screening test or triple test (if patient came to our clinic after $14^{\text {th }}$ weeks) were offered to all women.

When the diagnostic work-up was completed, the couple was counseled by a multidisciplinary medical team that consisted of obstetricians, neonatologists, pediatriac surgeons and the other pediatric specialists, where the prognosis and treatment options were discussed. In the presence of lethal or severely disabling anomalies, if future parents required the TOP, induction of labor with misoprostol was started. For the pregnancies before $24^{\text {th }}$ week, $200 \mu \mathrm{g}$ misoprostol was administered vaginally every four hours for 48 hours. For those who had a uterine scar or pregnancies beyond 24 weeks, the dose wes reduced by half. Misoprostol administration was discontinued and oxytocin infusion was started whenever the Bishop's Score was $\geq 6$ regardless of when the last dose of misoprostol was administered. We started the infusion with $5 \mathrm{U}$ of oxytocin in $500 \mathrm{ml}$ Ringer's Lactate or saline at 8 drops per minute with an increment of 4 drops every 15 minutes up to a maximal dose of 32 drops per minute. If cervical dilatation was not obtained within 48 hours, \%0.1 Rivanol solution ( $20 \mathrm{ml}$ per gestational week) was instilled extra-amniotically using a transcervical Foley catheter which was introduced under sterile conditions. Hysterotomy was performed on the patients with a uterine scar in the third trimester or in whom extraamniotic Rivanol instillation was not sufficient for inducing labor. Additionally, from 24 weeks onward, fetocide was performed by injecting potassium chloride to the fetal heart. All patients were offered autopsy after the termination.

Medical and demographic characteristics of all cases were recorded. The data was analysed in two groups according to the period, as in 2002-2006 and 2007-2010. Also, the women were subdivided into two categories according to their gestational age; $<23$ weeks gestation (early termination) and $\geq 23$ weeks gestation (late termination). This study was approved by the Institutional Ethics Committee.

Calculations were performed using SPSS software (Version 11, Chicago, IL, USA). Descriptive parameters are expressed as mean $\pm \mathrm{SD}$. In order to compare the variables, $\mathrm{x}^{2}$, Fisher exact test and student's t test were applied. P values of $<0.05$ were considered as statistifically significant.

\section{Results}

A total of 962 TOPs due to fetal anomalies in single pregnancies were locally performed over the nine-year period. In 891 cases, misoprostol succesfully induced labor. In 20 cases, oxytocin infusion was started without misoprostol administration, as the cervix was already $2 \mathrm{~cm}$ dilated. Extra-amniotic rivanol instillation was performed on 45 cases due to the failure of induction using misoprostol. Of these cases, 20 were before 23 weeks of gestation and 25 were beyond 23 weeks. Six patients at the third trimester of gestation underwent hysterotomy due to a previous cesarean scar of uterus. Fetocide was performed on 344 cases with no major complications.

The demographic and obstetric characteristics of the women are summarized in Table 1. 458 (47.6\%) of TOPs were performed between 2002 and 2006 (Group 1) and 504 (52.3\%) of them were performed between 2007 and 2010 (Group 2). The number of early ( $<23$ weeks) and late ( $\geq 23$ weeks) terminations were $583(60.6 \%)$ and 379 (39.3\%), respectively. The mean maternal age was $26.7 \pm 5.5$ years in Group 1 and $27.7 \pm 6$ years in Group 2. The interruptions of pregnancy were performed at a mean gestational age of $22.4 \pm 5.4$ and $22.2 \pm 5.4$ weeks in

Table 1. Demographic and obstetric characteristics of the women studied by period

\begin{tabular}{|l|c|c|c|}
\hline & Group 1 & p & Group 2 \\
\hline The number of TOP & $458(47.6)$ & $504(52.3)$ & - \\
\hline Maternal age, year & $26.7 \pm 5.5$ & $27.7 \pm 6$ & 0.01 \\
\hline Parity, median (range) & $1(0-10)$ & $1(0-9)$ & $>0.05$ \\
\hline Gestational age at TOP, weeks & $22.4 \pm 5.4$ & $22.2 \pm 5.4$ & $>0.05$ \\
\hline Prenatal karyotype, n (\%) & $73(15.9)$ & $161(31.9)$ & 0.0001 \\
\hline TOP $<23$ weeks, n (\%) & $277(60.4)$ & $306(60.7)$ & 0.23 \\
\hline TOP $\geq 23$ weeks, n (\%) & $181(39.5)$ & $198(39.2)$ & 0.38 \\
\hline TOP: Termination of pregnancy & & & \\
\hline
\end{tabular}


Group 1 and 2, respectively. Prenatal karyotype analysis were performed more frequently in Group 2 with a rate of $31.9 \%$ (161), while only 73 (15.9\%) cases underwent karyotype analysis between 2002 and 2006 ( $p<0.0001)$. None of the parameters were statistically significantly different between the two groups except for the prenatal karyotype analysis.

All of the anomalies which led to the TOP were subdivided according to the affected system and they are listed in Table 2 . The vast majority of anomalies were central nervous sytem malformations (51.8\%). They were followed by multiple anomalies (10.2\%) and chromosomal anomalies (9.4\%). Chromosomal and cardiovascular system anomalies were significantly higher in 2007-2010 in comparison to 2002-2006 ( $<<0.0001$ and $p=0.002$, respectively). There were no significant differences between the other system anomalies when they were compared according to the period of time.

The distribution of fetal anomalies according to the gestational age during TOP is demonstrated in Table 3. Central nervous system anomalies, especially spina bifida and anencephaly, were the leading causes of both early and late terminations during the nine-year period. Among the TOPs between 2002 and 2006, multiple anomalies came second both in the early and late termination groups with $9.3 \%$ and $9.9 \%$, respectively. Chromosomal anomalies were the second most common cause of the TOP at all gestational ages between 2007 and 2010 (13.6\% in early, $13.2 \%$ in late termination). Among the chromosomal anomalies, trisomy 21 was the most common type. There was no statistically significant difference between the fetal indications that led to early termination compared to those that led to late termination in the total cohort.

In $143(14.6 \%)$ cases, a postmortem examination was performed. When we compared the prenatal and postmortem findings, we found complete agreement in 114 cases $(79.7 \%)$, and major agreement with additional findings in 29 cases (20.3\%). There was no significant disagreement in any of the cases.

Table 2. Fetal indications for termination of pregnancy by period

\begin{tabular}{|c|c|c|c|c|}
\hline & $\begin{array}{c}\text { Group 1 } \\
(2002-2006)\end{array}$ & $\begin{array}{c}\text { Group 2 } \\
(2007-2010)\end{array}$ & Total & $\mathbf{p}$ \\
\hline Central nervous system, n (\%) & $270(59)$ & $228(45.2)$ & $498(51.8)$ & 0.06 \\
\hline Chromosomal anomalies, n ( \%) & $26(5.7)$ & $64(12.7)$ & $90(9.4)$ & $<0.0001$ \\
\hline Genitourinary system n (\%) & $40(8.7)$ & $43(8.5)$ & $83(8.6)$ & 0.7 \\
\hline Cardiovascular system, n ( \%) & $8(1.7)$ & $26(5.2)$ & $34(3.5)$ & 0.002 \\
\hline Pulmonary system, n (\%) & $3(0.7)$ & $10(2)$ & $13(1.4)$ & 0.052 \\
\hline Gastrointestinal system, n (\%) & $7(1.5)$ & $6(1.2)$ & $13(1.4)$ & 0.8 \\
\hline Genetic diseases, n (\%) & $11(2.4)$ & $4(0.8)$ & $15(1.6)$ & 0.07 \\
\hline
\end{tabular}

\section{Discussion}

The prenatal diagnosis may result from routine screening by ultrasound and biochemical markers or from a specific parental request, for instance owing to a family history leading to genetic testing (4). The prevalence of chromosomally abnormal fetuses is reported to be $0.31 \%$ and that of chromosomally normal fetuses with major and minor malformations are $1.8 \%$ and $1.32 \%$, respectively (5). In countries with a routine ultrasound screening policy, more than half of all congenital anomalies are diagnosed prenatally, including $74 \%$ major and $46 \%$ minor abnormalities (6). Romosan et al. (5), found that the detection rate of major malformations in chromosomally normal fetuses were $68 \%$ with a detection rate of $37 \%$ at $<22$ weeks, and the corresponding detection rates of chromosomally abnormal fetuses were $46 \%$ and $33 \%$. These rates change according to the nature of the anomaly, as it is highest for malformations in the central nervous and genito-urinary systems, and lowest for malformations of skeletal and circulatory systems $(5,6)$.

In the present study, we analysed the alterations in fetal indications for TOP during the period between 2002 and 2010. For this, we divided the cohort into two groups according to years. Although the number of terminations in our clinic increased progressively, the number of TOPs due to central nervous system anomalies, especially anencephaly, were lower during the period between 2007 and 2010 (270/458 vs. 228/504). This might be a result of the increased use of pregestational and early gestational folic acid. Also, we found a significant rise in the cardiovascular system anomalies leading to the TOP within the last four years, which reflects the rise in the diagnosis of these anomalies in the pregnant population. The reason for this rise may be the growing use of echocardiogram as a complementary scan, as well as the increasing experience of fetal heart screening among the obstetricians in Turkey.

In our series, the most common chromosomal anomaly was trisomy 21 , which was consistent with the other studies $(4,7,8)$. The proportion of chromosomal anomalies leading to TOP has 
Table 3. Fetal indications for termination of pregnancy by gestational age

\begin{tabular}{|c|c|c|c|c|c|c|c|c|}
\hline & \multicolumn{2}{|c|}{$\begin{array}{c}\text { Group } 1(2002-2006) \\
n(\%)\end{array}$} & \multicolumn{2}{|c|}{$\begin{array}{c}\text { Group } 2 \text { (2007-2010) } \\
n(\%)\end{array}$} & \multicolumn{3}{|c|}{$\begin{array}{l}\text { Total } \\
\text { n (\%) }\end{array}$} \\
\hline & & $<23$ wk & $\geq 23 \mathrm{wk}$ & $<23$ wk & $\geq 23 \mathrm{wk}$ & $<23 \mathrm{wk}$ & $\geq 23 \mathrm{wk}$ & $\mathbf{p}$ \\
\hline \multirow{10}{*}{$\begin{array}{l}\text { Central } \\
\text { nervous } \\
\text { system }\end{array}$} & Spina bifida & 49 & 50 & 63 & 40 & 99 & 103 & \\
\hline & Anencephalus & 77 & 20 & 33 & 13 & 97 & 46 & \\
\hline & Hydrocephalus & 4 & 7 & 12 & 10 & 11 & 23 & \\
\hline & DWM & 3 & 5 & 2 & 8 & 8 & 10 & \\
\hline & ACC & 2 & 4 & 1 & 0 & 6 & 1 & \\
\hline & Holoprosencephalus & 5 & 6 & 5 & 1 & 11 & 6 & \\
\hline & Encephalocele & 11 & 6 & 18 & 4 & 17 & 22 & \\
\hline & Iniencephaly & 6 & 1 & 2 & 0 & 7 & 2 & \\
\hline & Other & 6 & 8 & 8 & 7 & 14 & 15 & \\
\hline & Total & $163(58.8)$ & $107(59.1)$ & $145(47.3)$ & $83(41.9)$ & $270(58.9)$ & $228(45.2)$ & 0.46 \\
\hline \multirow{7}{*}{$\begin{array}{l}\text { Chromosomal } \\
\text { anomalies }\end{array}$} & Trisomy 21 & 13 & 7 & 23 & 13 & 20 & 29 & \\
\hline & Trisomy 18 & 0 & 0 & 3 & 5 & 0 & 8 & \\
\hline & Trisomy 13 & 0 & 0 & 0 & 0 & 0 & 1 & \\
\hline & Turner & 2 & 1 & 8 & 2 & 3 & 10 & \\
\hline & Triploidy & 1 & 0 & 0 & 1 & 1 & 1 & \\
\hline & Other & 0 & 2 & 3 & 6 & 2 & 9 & \\
\hline & Total & $16(5.9)$ & $10(5.5)$ & $37(13.6)$ & $27(13.2)$ & $26(5.6)$ & $64(12.6)$ & 0.74 \\
\hline \multirow{7}{*}{$\begin{array}{l}\text { Genitourinary } \\
\text { system }\end{array}$} & Renal agenesis & 10 & 6 & 10 & 6 & 16 & 16 & \\
\hline & MCDK & 7 & 2 & 10 & 3 & 9 & 14 & \\
\hline & PCKD & 4 & 6 & 2 & 2 & 10 & 4 & \\
\hline & Hyronephrosis & 1 & 1 & 1 & 1 & 2 & 2 & \\
\hline & Cloaca anomaly & 0 & 0 & 1 & 1 & 0 & 2 & \\
\hline & Other & 3 & 0 & 5 & 0 & 3 & 5 & \\
\hline & Total & $25(9)$ & $15(8.2)$ & $30(9.8)$ & $13(6.5)$ & $40(8.7)$ & $43(8.5)$ & 0.48 \\
\hline \multirow[t]{7}{*}{$\begin{array}{l}\text { Musculoskeletal } \\
\text { system }\end{array}$} & $\begin{array}{c}\text { Lethal } \\
\text { skeletal dysplasia }\end{array}$ & 9 & 8 & 15 & 11 & 17 & 26 & \\
\hline & $\begin{array}{l}\text { Osteogenesis } \\
\text { imperfecta }\end{array}$ & 3 & 0 & 0 & 1 & 3 & 1 & \\
\hline & Hypophosphatasia & 1 & 1 & 1 & 0 & 2 & 1 & \\
\hline & Kyphoscolisosis & 2 & 1 & 1 & 0 & 3 & 1 & \\
\hline & FAS & 0 & 1 & 1 & 2 & 1 & 3 & \\
\hline & Other & 0 & 4 & 3 & 4 & 4 & 7 & \\
\hline & Total & $15(5.4)$ & $15(8.2)$ & $21(6.8)$ & $18(9)$ & $30(6.5)$ & $39(7.7)$ & 0.75 \\
\hline \multirow{7}{*}{$\begin{array}{l}\text { Cardiovascular } \\
\text { system }\end{array}$} & HLHS & 0 & 3 & 0 & 7 & 3 & 7 & \\
\hline & Ectopia cordis & 1 & 0 & 0 & 0 & 1 & 0 & \\
\hline & TOF & 1 & 0 & 2 & 1 & 1 & 3 & \\
\hline & DORV & 0 & 0 & 1 & 0 & 0 & 1 & \\
\hline & Complex anomalies & 0 & 0 & 1 & 4 & 0 & 5 & \\
\hline & Other & 1 & 2 & 4 & 6 & 3 & 10 & \\
\hline & Total & $3(1)$ & $5(2.6)$ & $8(2.6)$ & $18(8.3)$ & $8(1.7)$ & $26(4.9)$ & 0.52 \\
\hline
\end{tabular}




\begin{tabular}{|c|c|c|c|c|c|c|c|c|}
\hline \multirow{6}{*}{$\begin{array}{l}\text { Pulmonary } \\
\text { system }\end{array}$} & CCAM & 1 & 0 & 2 & 1 & 1 & 3 & \\
\hline & Laryngeal atresia & 1 & 0 & 1 & 0 & 1 & 1 & \\
\hline & Diaphragmatic hernia & 0 & 0 & 1 & 1 & 0 & 2 & \\
\hline & Hydrothorax & 0 & 1 & 1 & 2 & 1 & 3 & \\
\hline & Other & 0 & 0 & 1 & 0 & 0 & 1 & \\
\hline & Total & $2(0.7)$ & $1(0.5)$ & $6(1.9)$ & $4(1.9)$ & $3(0.6)$ & $10(1.9)$ & 0.69 \\
\hline \multirow{6}{*}{$\begin{array}{l}\text { Gastrointestinal } \\
\text { system }\end{array}$} & Omphalocele & 3 & 1 & 2 & 1 & 4 & 3 & \\
\hline & Gastrochisis & 0 & 0 & 1 & 0 & 0 & 1 & \\
\hline & Duedonal atresia & 0 & 1 & 0 & 1 & 1 & 1 & \\
\hline & Esophageal atresia & 0 & 1 & 0 & 1 & 1 & 1 & \\
\hline & Other & 0 & 1 & 0 & 0 & 1 & 0 & \\
\hline & Total & $3(1)$ & $4(2.2)$ & $3(0.9)$ & $3(1.5)$ & $7(1.5)$ & $6(1.1)$ & 0.62 \\
\hline \multirow{5}{*}{$\begin{array}{l}\text { Genetic } \\
\text { diseases }\end{array}$} & SMA & 5 & 0 & 2 & 0 & 5 & 2 & \\
\hline & Cystic fibrosis & 0 & 0 & 1 & 0 & 0 & 0 & \\
\hline & Thalassemia major & 1 & 2 & 1 & 0 & 1 & 1 & \\
\hline & Other & 3 & 2 & 0 & 0 & 5 & 1 & \\
\hline & Total & $9(3.2)$ & $2(1.1)$ & $4(1.3)$ & $0(0)$ & $11(2.4)$ & $4(0.7)$ & 0.52 \\
\hline \multirow[t]{3}{*}{ Face and neck } & Cystic higroma & 6 & 0 & 7 & 0 & 6 & 7 & \\
\hline & $\begin{array}{l}\text { Severe cleft lip } \\
\text { and palate }\end{array}$ & 1 & 0 & 0 & 0 & 1 & 0 & \\
\hline & Total & $7(2.5)$ & $0(0)$ & $7(2.2)$ & $0(0)$ & $7(1.5)$ & $7(1.3)$ & - \\
\hline \multirow{4}{*}{$\begin{array}{l}\text { Multiple } \\
\text { anomalies } \\
\text { Other }\end{array}$} & & $26(9.3)$ & $18(9.9)$ & $33(10.7)$ & $21(10.6)$ & $44(9.6)$ & $54(10.7)$ & 0.84 \\
\hline & Hydrops & 8 & 4 & 10 & 10 & 12 & 20 & \\
\hline & Amniotic band & 0 & 0 & 2 & 1 & 0 & 3 & \\
\hline & Total & $8(2.8)$ & $4(2.2)$ & $12(3.9)$ & $11(5.5)$ & $12(2.6)$ & $23(4.5)$ & 0.41 \\
\hline Total & & $277(100)$ & $181(100)$ & $306(100)$ & $198(100)$ & $458(100)$ & $504(100)$ & \\
\hline \multicolumn{9}{|c|}{$\begin{array}{l}\text { Wk: weeks, DWM: Dandy-Walker mlformation, ACC: agenesis of corpus callosum, MCDK: multicystic dysplastic kidney, PCKD: policystic kidney disease, } \\
\text { FAS: fetal-akinesia sequence, HLHS: hypoplastic left heart syndrome, TOF: tetralogy of Fallot, DORV: double outlet right ventricle, CCAM: congenital cystic adeno- } \\
\text { matoid malformation, SMA: spinal muscular atrophy }\end{array}$} \\
\hline
\end{tabular}

increased dramatically from $5.7 \%$ to $12.7 \%$ within the last four years. This might be a consequence of the increased number of women that undergo chromosomal screening tests in Turkey. Furthermore, more people accept karyotype analysis and the termination of the pregnancy with a chromosomal anomaly. In spite of the improvement in screening and detection of chromosomal anomalies in Turkey, the overall proportion of TOP due to chromosomal anomalies in our study (9.4\%) was still lower than that in the previous studies $(30-39 \%)(4,7,8)$. The reason for this low rate might be the religious and cultural factors which lead fewer couples to accept karyotype analysis or termination in comparison to the couples in Western countries. Moreover, Turkish people are more prone to terminate pregnancies because of the malformations that affect the external appearance (for instance the defects in face or extremities) rather than isolated chromosomal anomalies.

Wyldes et al. (9), in their study within the period between 1995 and 2004, showed that a significantly increasing proportion of cases occurred before 16 weeks ( $12.2 \%$ in 1995 vs $27.9 \% 2004$, $\mathrm{p}<0.00001$ ). Nuchal translucency (NT) measurement for the screening of Down syndrome increases the possibility to detect certain types of fetal malformations, such as acrania, at the end of the first trimester. The detection rate of structural abnormalities at 11-14 gestational weeks varies between $18 \%$ and $65 \%$ in the literature (10). Early detection of anomalies is very important, since it allows the termination process to be at an earlier stage of gestation when the psychological burden and physical morbidity due to the TOP is less severe. In our series, there was no significant difference in the mean of the gestational age between 20022006 and 2007-2010. Although the rate of TOP beyond 24 weeks gestation is $8.4 \%$ in UK and $6.6 \%$ in Europe, the rate of late termination was as high as $39.3 \%$ in our population $(2,9)$. The main reason for this high rate is that the laws permit the TOP at any gestational age in Turkey. Termination after fetocide is legally performed even in the last months of pregnancy in the presence of severe fetal malformation, leading pregnant women to act slowly and waste time making the decision regarding TOP. Women who are hesitant regarding the TOP, especially, 
make a decision many weeks after the diagnosis. Moreover, ultrasonography is performed routinely in the third trimester in Turkey, enabling the detection of late-onset malformations at later stages of gestation. Finally, our unit is a tertiary center where patients are referred after several steps of examination in other hospitals. This might be another reason for the delay in the termination process.

In a study which compares the indications of terminations before and after 20 weeks, it was found that, while TOPs for karyotype anomalies were more common in early gestation, those for cardiac anomalies were more frequent after 20 weeeks gestation (11). As prenatal screening strategies are designed to detect fetal karyotype anomalies in the first and early second trimester, they are more frequently diagnosed prior to 20 weeks' gestation. Likewise, Garne et al. (2) reported that late TOP was more often performed for a nonchromosomal isolated major structural anomaly and less often for a fetus with a chromosomal syndrome or multiple anomalies. In our study, there were no statistically significant differences between early and late terminations for the indications of TOP. Central nervous system anomalies accounted for more than half of the indications for both early and late terminations. This finding is consistent with the studies which showed that central nervous system malformations are the most common structural malformations leading to the TOP $(4,7,8,12,13)$.

Fetal autopsy has a particularly valuable role in the counseling of families after the TOP (14). Especially when prenatal diagnosis is based on the results of ultrasound scan only, autopsy may provide important information that changes the estimated risk of recurrence (13). Boyd et al. (13) reported that, in $27 \%$ of cases, information from the autopsy examination led to a refinement of the risk of recurrence, and in $8 \%$ this was increased to a one in four risk. Several studies have reported a progressive decline in the autopsy rates (15). The reason for this decrease has been speculated to be the physician and parental belief in the diagnostic capability of ultrasound and adjunctive testing modalities, as well as the obligation to obtain an autopsy consent (15). In our series, only $14.6 \%$ of the parents accepted a postmortem examination. We believe that this is mostly because of the religious and cultural considerations in the Turkish population, as well as the inadequate comprehension of the need and benefits of autopsy.

In conclusion, the distribution of indications for the TOP was influenced by the development in prenatal screening policy resulting in a significant increase in terminations due to chromosomal and cardiovascular system anomalies. Cultural, educational, religious and legal factors cause differences in the indications for TOP as well as the gestational age that TOPS are performed.

\section{Conflict of interest}

No conflict of interest was declared by the authors.

\section{References}

1. Bijma HH, van der Heide A, Wildschut HIJ. Decision-making after ultrasound diagnosis of fetal abnormalitiy. Reproductive Health Matters 2008; 16: 82-9. [CrossRef]

2. Garne E, Khoshnood B, Loane M, Boyd P, Dolk H; EUROCAT Working Group. Termination of pregnancy for fetal anomaly after 23 weeks of gestation: a European register-based study. BJOG 2010; 117: 660-6. [CrossRef]

3. Aslan H, Yildirim G, Ongut C, Ceylan Y. Termination of pregnancy for fetal anomaly. International Journal of Gynecology and Obstetrics 2007; 99: 221-4. [CrossRef]

4. Dommergues M, Mandelbrot L, Mahieu-Caputo D, Boudjema N, Durand-Zaleski I, the ICI Group-Club de medecine foetale. Termination of pregnancy following prenatal diagnosis in France: how severe are the foetal anomalis? Prenat Diagn 2010; 30: 531-9.

5. Romosan G, Henriksson E, Rylander A, Velentin L. Diagnostic performance of routine ultrasound screening for fetal abnormalities in an unselected Swedish population in 2000-2005. Ultrasound Obstet Gynecol 2009; 34: 526-33. [CrossRef]

6. Grandjean H, Larroque D, Levi S. Sensitivity of routine ultrasound screening of pregnancies in the Eurofetus Team. Annals of the New York Academy of Science 1998; 847: 118-24. [CrossRef]

7. Vaknin Z, Ben-Ami I, Reish O, Herman A, Maymon R. Fetal abnormalities leading to termination of singleton pregnancy: the 7-year experience of a single medical center. Prenat Diagn 2006; 26 : 938-43. [CrossRef]

8. Guillem P, Fabre B, Cans C, Robert-Gnansia E, Jouk PS. Trends in elective termination of pregnancy between 1989 and 2000 in French county (the Isere). Prenat Diagn 2003; 23: 877-83. [CrossRef]

9. Wyldes MP, Tonks AP. Termination of pregnancy for fetal anomaly: a population-based study 1995 to 2004 . BJOG 2007; 114: 639-42. [CrossRef]

10. Salvedt S, Almström H, Kublickas M, Valentin L, Grunewald C. Detection of malformations in chromosomally normal fetuses by routine ultrasound at 12 or 18 weeks of gestation- a randomised controlled trial in 39,572 pregnancies. BJOG 2006; 113: 664-74. [CrossRef]

11. Dickinson JE. Late pregnancy termination within a legislated medical environment. Aust N Z J Obstet Gynaecol 2004; 44: 337-41. [CrossRef]

12. Bosma JM, van der Wal G, Chamberlain PF. Autopsy after termination of pregnancy for fetal anoaly: retrospective cohort study. BMJ 2004; 328: 137-40. [CrossRef]

13. Boyd PA, Tondi F, Hicks NR, Chamberlain PF. Autopsy after termiantion of pregnancy for fetal anomaly: retrospective cohort study. BMJ 2004; 328: 137-40. [CrossRef]

14. Dong-Zhi L, Mei Y. Autopsy after termination of pregnancy for fetal anomaly in Mainland China. Prenat Diagn 2007; 27: 1183-4. [CrossRef]

15. Dickinson JE, Prime DK, Charles AK. The role of autopsy after following pregnancy termination for fetal abnormality. Aust $\mathrm{N} \mathrm{Z} \mathrm{J}$ Obstet Gynaecol 2007; 47: 445-9. [CrossRef] 